\title{
Hour Times Gram per Milliliter
}

National Cancer Institute

\section{Source}

National Cancer Institute. Hour Times Gram per Milliliter. NCI Thesaurus. Code C85613.

Hours times grams per milliliter. 